DOI: $10.31866 / 2410-1915.21 .2020 .208252$

UDC 008+316.422.44

\title{
SCIENTIFIC AND TECHNOLOGICAL PROGRESS IN THE CONTEXT OF DEVELOPMENT OF “TECHNOLOGICAL” SOCIETY
}

\author{
Julia Trach
}

PhD in Pedagogical Sciences, Professor, ORCID: 0000-0003-2963-0500,0411@ukr.net, Kyiv National University of Culture and Arts, 36, Ye. Konovaltsia St., Kyiv, 01133, Ukraine

\section{For citations:}

Trach, J. (2020). Scientific and Technological Progress in the Context of Development of "Technological" Society. Culture and Arts in the Modern World, 21, 172-181. https://doi.org/10.31866/24101915.21.2020.208252.

The purpose of the article is to find out the essence of scientific and technological progress as a factor of development of "technological" society. The research methodology is based on the principles of integrity and systematic nature, which could reveal major contradictions in the development of modern technologies related to their impact on contemporary culture. The scientific novelty is to clarify the importance of scientific and technological progress for the development of a "technological" society, to find out the impact of engineering and technology, including information and communication, on modern culture. Conclusions. Sociocultural progress is largely related to the progress of technology and its application for the development of science. The importance and role of technology in sociocultural development throughout human history have grown steadily, reaching an unprecedented level today. The interaction of technology, information and traditional culture and their joint impact on all spheres of human activity is extremely complex, giving rise to many sociocultural issues. However, disputes over the technique's future concern, not so much technology itself, but the future of civilisation. Humanity is vitally interested in technology, thought as the only common phenomenon of human culture, which has become a factor that largely determines the further development. One of the main causes of many so-called techno-problems is the gap between technology and culture; in the predominance of the paradigm of the dominant role of science and technology in the general development of civilisation in the rather large period of society, in the emergence of this "mass culture". Therefore, the concern of the objectives and solutions to the problems afflicting cultural studies today requires the formation of a new paradigm of understanding and attitude toward technology in society, including the definition of its role in modern culture and sociocultural transformation's tools. This refers to a patently controlled process of creating and making extensive use of the technologies required for the betterment of all people.

Keywords: engineering; technology; scientific and technological progress; “technological” society.

(C) Julia Trach, 2020 


\section{Introduction}

Ever since the beginning of technology, it has been a unique tool for the transformation of human society. Nowadays it increasingly influences on various aspects of life in society, both positively and negatively, promoting a global, technological environment. Despite the significance of engineering and technology in the process of sociocultural transformations, today, on the one hand, we must note a few belated understanding of the importance of this issue. Moreover, there are views that technology is beyond culture, and that people are within technology's power. Actually, there is a breaking crisis about engineering and overall technology, which requires a comprehensive analysis of their status and role in the sociocultural processes.

On the other hand, the contradiction between two approaches requires the humanities research of the technology phenomenon: a) over-optimistic evaluation of the achievements and prospects of modern technological development, and b) a very critical attitude towards technological progress in society (especially in the humanitarian environment). This approach to engineering and technologies due to the fact that because of the peculiarities of their development they make number of issues the cultural studies' mission, in particular we are talking about changes in culture, identifying trends and the like. The consideration of the role of engineering and technology in sociocultural transformation is an outstanding scientific, cultural task, because "first of all it is necessary to overcome naturalistic, equipment-oriented view of technology. To replace it the understanding of the technology, on the one hand, as a manifestation of the intricate intellectual and sociocultural processes, on the other - as a special environment, imposing it environmental archetypes, rhythms of the functioning, aesthetic, etc., should come" (Rozin, 2008, p.48).

The study of technology as a determining factor of social development at different stages have been studied by many scientists, including V. Stopin, E. Demidenko, the authors of the concepts of industrial civilisation, the supporters of the concepts of tehno-optimism (F. Dessauer, H. Kahn, D. Bell, A. Toffler and others) and techno-pessimism (A. Spengler, K. Jaspers, H. Marcuse, J. Ellul, and others) and many others. Selected issues of the theory and practice of scientific and technological progress are discovered in the works by S. Kara-Murza, Yu. Lotman, Yu. Konkin, Yu. Yakovets, etc. Engineering and technology through the analysis of their global impacts are examined by E. Agazzi, L. Iris, J. Grant, J. Galbraith, L. Mumford, K. Popper and others. Their works consider the general issues on the technology development, identify methodological issues of its analysis, attempt to identify social and cultural implications of advances in science and technology that occurred in the second half of the twentieth century. However, this issue requires attention regarding engineering and technological impact on culture, determination of the essence of scientific and technological progress as an overall factor of development of "technological" society. 


\section{Purpose of the article}

The article clarifies the essence of scientific and technological progress as a factor in the development of "technological" society. The research methodology is based on the principles of integrity and consistency, which allowed identifying the main contradictions in the development of modern technology related to their impact on contemporary culture.

\section{Main research material}

The technology has been used by mankind at all stages of its development, it is a natural process - "in fact, human activity and culture have a technical background" (Rozin, 2006). However, today, in the era of so-called industrial civilisation, the development of engineering and technology despite its advantages has turned violent to people. This is reflected in the quantitative and qualitative diversity of technical means and their deep penetration into the life of modern man and society overall, which are largely dependent on the mancaused environment, which ultimately determines the comprehensiveness of the influence of technology on social and cultural reality. The main features of the "technological" society are the internalisation of the human activities; the formation of the techno-sphere; the increasing sociocultural values and educational activities; the growth of education and training level; the formation of "mass culture"; the emergence of men's fresh issues related to style and pace of life, the system of cultural and ethical values, the increasing role of the interaction of science, the interdisciplinary study of global issues, etc.

The study of engineering and technology as a basis of industrial civilisation and the means of social and cultural transformation is directly related to the identification of the essence of scientific and technological progress, whereby it is usually thought of as a single, interdependent, ongoing development of science and technology, which origins come from the manufacturing production of the $16^{\text {th }}$ - the $18^{\text {th }}$ centuries, when scientific and technical activities have moved closer (Volkov, n.d.). The scientific and technological progress were the hitherto two, mediated, but quite separate areas of human activity (Volkov, n.d.). It was at the time of the manufacturing production when the first scientific and engineering elements of the large industry began to develop, which became the basis for the development of the industrial revolution - the first phase of scientific and technological progress. The second stage is characterised by the fact that science and technology incite to each other's development with increasing speed, that it is now possible owing to the machine production, which has opened up new and novel opportunities for technological employment of science (Volkov, n.d.). It is the combination of science and technology is the difference in the onrush of engineering and technologies. The acceleration factor of technical progress has been affected and is being influenced by many areas of the social sciences in different ways, for example, industrial management, the logic of engineering creativity, etc., and fundamentally new ideas in biology, psychology, linguistics, etc. Thus, science is spreading revolutionary ideas in engineering which in turn 
constantly stimulates the progress of science, putting forward new demands and challenges: "technological progress within human history occurred on the same pattern: continuous growth of technical improvement both reflected the continuous process of social changes and increased expanding of it, moreover, the specifics of sociocultural forms of organisation and transformation contributed the technical progress significantly" (Ilin, 2003, p. 167).

And finally, the third stage of scientific and technological progress that began in the mid-1950s, associated with the expansion of the technological revolution - the next step in the development of productive forces, the transformation of science into a key factor of production. Modern scientific and technological progress covers not only industry, as it was before, but also education, transportation, communication, medicine, agriculture, governance and everyday life, which is evidence of progressive, revolutionary changes in society. The progress is based on onrush cross-development of science, engineering and technology, the increasing of technological determinism of social life and, consequently, expanding the pace of social and cultural changes. It is a "powerful social process associated with radically transforming the nature of productive activities based on the widespread displacement of human labour, rationalisation and intellectualisation of life by the power conversion knowledge for a direct and largely critical of technological strength" (Ilin, 2003, p. 5). This scientific and technological revolution became possible due to innovative technologies, which not only accelerated the technological development of civilisation in different directions but also led to significant social and cultural transformations. Among the most significant technology, in addition to the steam engine and the combustion engine, electric energy industry and aircraft manufacturing, the most significant is information technology, which has become the extremely effective initiator, first of all, for economic activity, and scientific and technical transformations as well as thereafter sociocultural ones, and followed by the so-called high-tech solutions, which is in rapid evolution: nano-bio technologies, etc. However, the central feature of the scientific and technological revolution is not the outstanding scientific findings, not a restructuring of the overall production process, namely it is to be provided based on scientific and technological progress with positive sociocultural transformations: it affects all aspects of society, including culture, human psychology, the relationship between society and nature, a change of consciousness and way of thinking, etc. For reference: according to experts of the Organization for Economic Co-operation and Development, in the mid-twentieth century, the economic growth rate was defined by the technology progress of $38 \%$, and at the end of the century - already of $65 \%$. It is generally assumed that this factor causes about $75 \%$ of the productivity gain, more than $50 \%$ of the increase of the national income increment, and effectively reduces the production prime cost. According to the UK Commission for Employment and Skills, a $60 \%$ increase in the overall efficiency of the American and Japanese industry is due to the changes in technology (Khodykina, 2005, p. 9).

This scientific and technological revolution is called as informational proceeding from the revolutionary changes introduced by information technolo- 
gies in various life spheres of society, wherein a combination of society, bioand technosphere into a single unit is taking place; consolidation of the technosphere' role in socio-natural and sociocultural processes is occurring. We are talking about the formation of the technosphere as basics of the artificial material world. The technical aspect of the informational revolution has trigged the development of a new culture, culture of information-oriented society which is being shaped. However, the most important result of the development of information communication technologies is a process of mutual proliferation of cultures. Such processes within a rather limited scale have occurred in antiquity, but only in the second half and in the late nineteenth century, this process became a global phenomenon. Radio, television, film, Internet and other mass media helped to spread the American popular culture, and cultural patterns of Europe and some Asian regions in the spiritual and cultural space worldwide. Technological tools, especially the media, has had a decisive impact, for information technologies are all technologies of culturogenesis. We are talking about culturogenesis function of information technologies, the essence of which is that they have the auto-generated effect - computers and software can and are used to produce of its kind artefacts in scale that is extended.

The development of the information revolution has expanded the "field of opportunities" for the development, creation and meeting new demands. Human requests, human choices become more critical determinants of scientific, technical, economic, and social development. Today there is "the growth of intellectual and behavioural autonomy of the individual" (Vasilchuk, 1991, p. 17), and a weakening of ties between social groups and individuals that they include, the erosion of social-group identity and the like. Determinacy of group cultures is replaced by convergence and homogenization of ways of life, motives and norms of behaviour, which is translated into the notions of "mass man" "mass culture", "mass", and it puts the person in a position of cultural and psychological loneliness. Besides, we have to acknowledge the marginalization of large segments of the population, the changing of values, ideals, needs of modern man, etc.

It is worth noting that the methods of mathematical description and information measurement were used in the development of the theory of the information society that appealed to the ever-increasing of information content, which, in fact, stated the increase of communicative acts, whereas their "efficiency", we mean, the growth rate of the new knowledge, could remain zero. For the information concepts have got this drawback, critical theories have emerged almost simultaneously in the social sciences and humanities, maintaining that the information revolution not only does create a knowledge society but, on the contrary, creates an environment in which the production of new knowledge grows problematic. This situation prompted the theoretical and methodological need to disclose the substantive component of the engineering and technological process, stipulating the use of the concept of "knowledge revolution", which precisely reflects the qualitative changes in the ways of producing new knowledge.

As a result of differentiation of the notions of "information" and "knowledge" to reveal the essence of phenomena of information and knowledge revolutions and their comparison, the researchers note that the information rev- 
olution is not accompanied by knowledge, but rather obstructs it. The reason for this is the absence of patterns, contradictory and fragmentary nature of the continuous information flow that leads to the formation of an equally contradictory and fragmented picture of the world. Also, the development of modern information technology has created a special symbolic reality, which consists of a continuous flow of simulacra that person either does not know and understand or responds to it emotionally.

Whereas, above all, engineering and technology-driven processes and phenomena, which are most closely connected with the development of computer technology and scientific areas of direct relevance to this kind of technology, other scholars argue about the onset of the computer revolution, while noting that it is impossible to outline its boundaries to separate from the other components of those processes which are characterised as the above mentioned "technological revolution", "information revolution", "knowledge revolution", "society informatisation" and the like. However, without naming the revolution it as the information, or knowledge, or computer one, precisely because of revolutionary changes, scientists were able to build virtual models and manipulate them to process huge amounts of primary information instantly to obtain scientific information. Scientific findings and inventions immediately become inheritage. Education, based on information and communication technologies, becomes public, continuous, remote, significantly increases the speed and efficiency of acquiring new knowledge and skills to the rising generation. The spread of new moral norms becomes easier. Global spiritual space, the world fund are formed. It presents values of each nation, ethnicity, civilisation, and from which anyone can learn according to their needs and individual taste. Thus, the information revolution was, in fact, the new sociocultural phenomenon that has shaped modern civilisation. Note, however, that the danger of the information revolution in the humanitarian sphere is less obvious, but of any importance in the long term, because it conflicts with the humanisation of society.

Exploring the influence of engineering and technology for culture, one should consider the type of sociality that has developed during the last century (Rozin, 2008, p. 48). "As long as we think that technology is the most important, and basic social problems are solved on its basis, and the welfare of mankind linked to the development of modern technology directly, we will continue to contribute to the deepening of the crisis of our civilisation. Although in our industrial civilisation the technology plays a huge role, from the perspectives of the development, one needs to promote the understanding that these things are different. We can no longer meet the prevailing type of sociality, the belief that basic social problems can be solved on the basis of the technology is becoming more and more destructive with time. Every society and culture involve technology, but not fully governed by it" (Rozin, 2008, p. 48). The technology should be considered as a phenomenon that is part of the culture of modernity that contributes significantly to spiritual values, sociocultural relationships of civilisation, but no more.

Thus, the main contradiction of modern industrial civilisation is that modern technology, on the one hand, opens up incredible opportunities for meeting and even creating human needs, and on the other, creates danger of destruction of the 
human existence backgrounds. J. Généreux (2001), Professor in Economics from France, arguing critically on the economic rules of modern society, eloquently described the sociocultural contradictions of the "technological" society: "Never our ability to produce wealth has been so enormous before, never our inability to govern the prosperity for all people has been so obvious". Consequently, the scope and rate of changes in social life, caused by the scientific and technological revolution, urgently generate a need for up-to-date and as complete as possible foreseeing of the totality of their consequences in different spheres of the living environment of modern society, including the field of culture.

\section{Conclusions}

Much of sociocultural progress is owed to advances in technology and its application in the process of scientific evolution. Mankind has accumulated its centuries-long experience, techniques, methods of cognition and transformation of nature within the technology. Thus, it should be seen as a means of sociocultural transformation. The importance and role of technology in sociocultural development throughout the history of humanity have grown steadily, reaching today, in the era of technological civilisation, unprecedented level. The most important feature of the present-day stage of civilisation development is, on the one hand, dynamic generation of the information society, and on the other, the society that covered by the engineering in all its bearings, is growing increasingly as "technological". The interaction of technology, information and traditional culture and their joint influence on modern civilisation is extremely complex, creating, among other things, numerous sociocultural problems of today. However, disputes over the technique's future concern, not so much technology itself, but the future of civilisation. Humanity is vitally interested in technology, thought as the only common phenomenon of human culture, which has become a factor that largely determines the further development. Certainly, the search for protective mechanisms must meet the requirements of the biosphere protection against the negative impacts of scientific and technological progress except for a complete rejection of technology.

The cause of many techno-problems is the emergence of the gap between technology and culture; the overrepresentation of the dominant role of science and technology paradigm in the overall development of civilisation for a long period of society development, and as a result, the generation of "mass culture". Therefore, the concern of the objectives and solutions to the problems afflicting cultural studies today requires the formation of a new paradigm of understanding and attitude toward technology in society, including the definition of its role in modern culture and sociocultural transformation's tools.

\section{References}

Généreux, J. (2001). Manifeste pour l'économie humaine [Manifesto for the human economy]. Esprit, 7, 141-171. https://esprit.presse.fr/article/genereux-jacques/ manifeste-pour-l-economie-humaine-9022?folder=2 [in French]. 
Ilin, V. V.(Ed.). (2003). Filosofiia nauki i tekhniki [The philosophy of science and technology]. Izdatelstvo MGTU imeni N. E. Baumana [in Russian].

Khodykina, V. V. (2005). Mizhnarodna naukovo-tekhnichna intehratsiia Ukrainy $v$ konteksti stratehii innovatsiinoho rozvytku [International scientific and technical integration of Ukraine in the context of innovation development strategy]. (Abstract of $\mathrm{PhD}$ Dissertation). Donetsk National University, Donetsk [in Ukrainian].

Lotman, J. M., \& Gomel, I. (1991). Technological Progress as a Problem in the Study of Culture. Poetics Today, 12, 4, 781-800. https://doi.org/10.2307/1772717 [in English].

Rozin, V. M. (2006). Krizis tekhnogennoi tcivilizatcii i puti vykhoda iz nego [The crisis of technological civilisation and ways out of it. In the Concept and modern concepts of technology]. In Poniatie i sovremennye kontceptcii tekhniki [The concept and modern concepts of technology] (Chapter 5, pp. 208-249). IF RAN [in Russian].

Rozin, V. M. (2008). Istoriia i filosofiia nauki [History and philosophy of science]. Iurait [in Russian].

Vasilchuk, Iu. A. (1991). Epokha NTR: masshtaby peremen [The era of scientific and technological revolution: the scale of change]. Polis, 1-3, 15-28 [in Russian].

Volkov, G. N. (n.d.). Nauchno-tekhnicheskii progress [Scientific and technological progress]. In Bolshaia sovetskaia entciklopediia [Great Soviet Encyclopedia]. https://dic. academic.ru/dic.nsf/bse/112708/\%D0\%9D\%D0\%B0\%D1\%83\%D1\%87\%D0\%BD\%D0\%BE [in Russian].

\section{НАУКОВО-ТЕХНІЧНИЙ ПРОГРЕС У КОНТЕКСТІ РОЗВИТКУ «ТЕХНОГЕННОГО» СУСПІЛЬСТВА}

Трач Юлія Василівна

Кандидат педагогічних наук, професор, ORCID:0000-0003-2963-0500,0411@ukr.net, Київський національний університет культури і мистецтв, Київ, Україна

Мета статті - з'ясувати сутність науково-технічного прогресу як чинник розвитку «техногенного» суспільства. Методологія дослідження грунтується на принципах цілісності і системності, що уможливило виявлення основних протиріч у розвитку сучасних технологій, пов'язаних з їхнім впливом на сучасну культуру. Наукова новизна полягає в уточненні значення науково-технічного прогресу для розвитку «техногенного» суспільства, з'ясуванні впливу техніки і технологій, зокрема інформаційно-комунікаційних, на сучасну культуру. Висновки. Соціокультурний прогрес багато в чому пов’язаний із прогресом техніки і застосуванням у процесі їі розвитку науки. Значення і роль техніки в соціокультурному розвитку протягом усієї історії людства постійно зростали, досягнувши сьогодні нечуваного рівня. Взаємодія техніки, інформації і традиційної культури та їхній спільний вплив на всі сфери життєдіяльності людини має надзвичайно складний характер, породжуючи, в тому числі, і численні соціокультурні проблеми. Однак суперечки про майбутнє техніки 
стосуються не стільки самої техніки, скільки майбутнього цивілізації. Людство життєво зацікавлене в техніці, що розуміється як єдиний загальний феномен загальнолюдської культури, який перетворився на чинник, який багато в чому визначає подальший розвиток. Одна з головних причин виникнення багатьох так званих технопроблем - у розриві між технікою і культурою; в переважанні в досить великому періоді розвитку суспільства парадигми домінуючої ролі науки і техніки в загальному розвитку цивілізації, в появі в зв’язку з цим «масової культури». Тому важливість завдань і вирішення проблем, що стоять сьогодні перед культурологією, вимагає формування нової парадигми розуміння і ставлення до техніки в суспільстві, в тому числі визначення її ролі в сучасній культурі і серед інструментів соціокультурних перетворень. Йдеться про свідомо керований процес створення i широкого використання технологій, необхідних для поліпшення життя всіх людей.

Ключові слова: техніка; технології; науково-технічний прогрес; «техногенне» суспільство.

\section{НАУЧНО-ТЕХНИЧЕСКИЙ ПРОГРЕСС В КОНТЕКСТЕ РАЗВИТИЯ «ТЕХНОГЕННОГО» ОБЩЕСТВА}

\section{Трач Юлия Васильевна}

Кандидат педагогических наук, профессор, ORCID: 0000-0003-2963-0500,0411@ukr.net, Киевский национальный университет культуры и искусств, Киев, Украина

Цель статьи - выяснить сущность научно-технического прогресса как фактор развития «техногенного» общества. Методология исследования основана на принципах целостности и системности, что позволило выявить основные противоречия в развитии современных технологий, связанных с их влиянием на современную культуру. Научная новизна заключается в уточнении значения научно-технического прогресса для развития «техногенного» общества, выяснении влияния техники и технологий, в частности информационно-коммуникационных, на современную культуру. Выводы. Социокультурный прогресс во многом связан с прогрессом техники и применением в процессе ее развития науки. Значение и роль техники в социокультурном развитии на протяжении всей истории человечества постоянно росли, достигнув сегодня неслыханного уровня. Взаимодействие техники, информации и традиционной культуры и их совместное воздействие на все сферы жизнедеятельности человека имеет чрезвычайно сложный характер, порождая, в том числе, и многочисленные социокультурные проблемы. Однако споры о будущем техники касаются не столько самой техники, сколько будущего цивилизации. Человечество жизненно заинтересовано в технике, понимаемой как единый общий феномен общечеловеческой культуры, превратившийся в фактор, который во многом определяет дальнейшее развитие. Одна из главных причин возникновения многих так называемых технопроблем - в разрыве между техникой и культурой; в преобладании в достаточно большом периоде развития общества парадигмы 
доминирующей роли науки и техники в общем развитии цивилизации, в появлении в связи с этим «массовой культуры». Поэтому важность задач и решения проблем, стоящих сегодня перед культурологией, требует формирования новой парадигмы понимания и отношения к технике в обществе, в том числе определение ее роли в современной культуре и среди инструментов социокультурных преобразований. Речь идет о заведомо управляемом процессе создания и широкого использования технологий, необходимых для улучшения жизни всех людей.

Ключевые слова: техника; технологии; научно-технический прогресс; «техногенное» общество. 